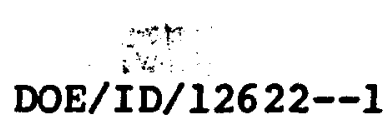

DE91 011219

\title{
K-AR DATING OF YOUNG VOLCANIC ROCKS
}

\author{
FINAL REPORT \\ Prepared for:
}

The U.S. Department of Energy Geothermal Technology Division

State Cooperative Geothermal Research

Grant Number: DE-FG07-86ID12622

Prepared by:

Paul E. Damon

Muhammad Shafiqullah

THE UNIVERSITY OF ARIZONA
Department of Geosciences

January 31, 1991

\section{SUMMARY}

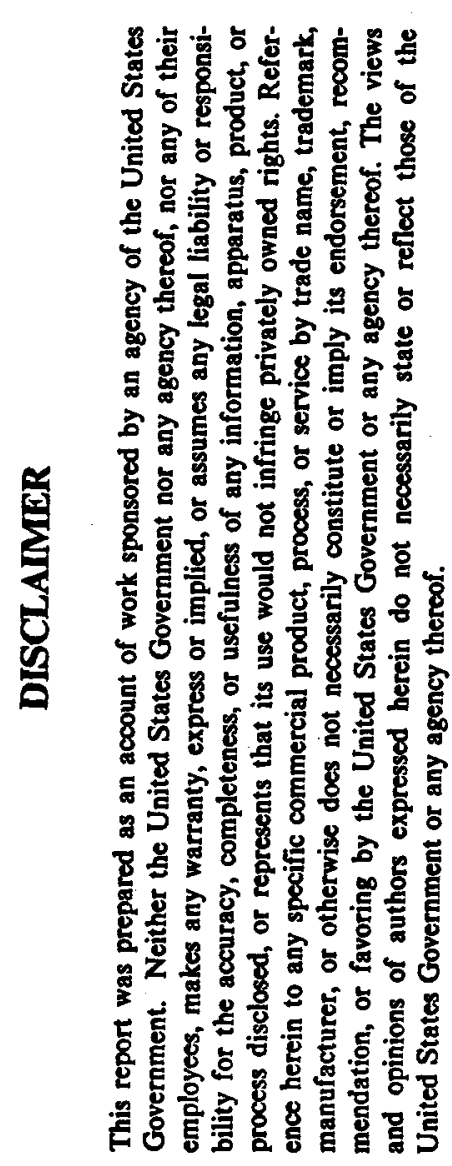

Potassium-Argon (K-Ar) age dates were determined for forty two young geologic samples by the Laboratory of Isotope Geochemistry, Department of Geosciences, in the period February 1, 1986 to June 30, 1989. Under the terms of Department of Energy Grant No. DE-FG07-86ID12622, The University of Arizona was to provide stateof-the-art K-Ar age dating services, including sample preparation, analytical procedures, and computations, for forty two young geologic samples submitted by DOE geothermal researchers. We billed only for forty samples.

Age dates were determined for geologic samples from five regions with geothermal potential: the Cascade Mountains (Oregon); the Cascade Mountains (Washington); Ascension Island, South Atlantic Ocean; Cerro Prieto, Mexico; and Las Azufres, Mexico. The ages determined varied from 5.92 m.a. to 0.62 m.a. The integration of KAr dates with geologic data and the interpretation in terms of geologic and geothermal significance has been reported separately by the various DOE geothermal researchers.

Table 1 presents a detailed listing of all samples dated, general sample location, researcher, researcher's organization, rock type, age, and probably error (1 standard deviation). Additional details regarding the geologic samples may be obtained from the respective geothermal researcher. 


\section{DISCLAIMER}

Portions of this document may be illegible in electronic image products. Images are produced from the best available original document. 
K-Ar dating Procedure at the University of Arizona

\section{sample preparation}

For groundmass feldspar concentrate, large phenocrysts, if any, were removed by hand picking. Samples were then ground to 100-150 um. Glass and altered minerals were separated by floatation on a heavy liquid of specific gravity $2.50-2.55$. Kpoor minerals such as olivine and pyroxene were separated using a heavy liquid of specific gravity 2.90-2.96. The concentrate of feldspar and feldspar rich composite grains were leached in dilute HF to remove any adhering glass, clay and carbonate and then resieved to remove the finer grains. The resultant culled groundmass was used for $K-A r$ dating. Pure feldspar was separated using standard magnetic and heavy liquid separation techniques.

\section{R-Analysis}

Potassium is analyzed on a Perkin-Elmer model 403 atomic absorption spectrophotometer. Three splits of each sample are taken in solution with $\mathrm{HF}$, buffered with $\mathrm{NaCl}$, and brought to a standard volume. A rock standard is run concurrently with each sample to monitor precision. Analyses are repeated if the spread between extreme measured values exceeded $1.5 \%$ and/or the measured potassium content of the standard differ by more than $2 \%$ from the accepted value.

\section{Ar-Analysis}

Samples for argon analyses are fused in induction-heated molybdenum crucibles suspended in $90 \mathrm{~mm}$ air cooled pyrex fusion envelopes, which have first been evacuated and baked for 2 days at $257^{\circ} \mathrm{C}$. The gas resulting from each fusion, after being thoroughly purified, is divided into two or more aliquot for separate analyses by static mode using our 6 inch $(15.24 \mathrm{~cm}), 60^{\circ}$ sector field, Nier type gas source mass spectrometer. A dedicated table top micro computer changes the magnetic field to focus each ion beam, in turn, on a Faraday cup collector and then measures and stores the voltages generated. Measurements are time regressed to the time gas is introduced, using both linear and parabolic least squares regression routines, and also on mass intensity ratios. If analyses in different aliquot do not fall within expected statistical limits, additional fusions and analyses are performed until satisfactory results are obtained. 
Table 1. Samples dated at the University of Arizona by K-Ar method under DOE Grant NO. DE-FGo7-86ID12622

\# Researcher

1 DL Nielson

2 DL Nielson

3 DL Nielson

4 DL Nielson

5 DL Nielson

6 DL Nielson

7 DL Nielson

8 DL Nielson

9 G Priest

10 G Priest

11 G Priest

12 G Priest

13 G Priest

14 G Priest

15 G Priest

16 G Priest

17 G Priest

18 G Priest

19 G Priest

20 G Priest

21 G Priest

22 G Priest

23 G Priest

24 G Priest

$25 \mathrm{~J}$ Moore

26 J Moore

27 J Moore

$28 \mathrm{~J}$ Moore

29 J Moore

$30 \mathrm{~J}$ Moore

31. M Korosec

32 M Korosec

33 M Korosec

34 M Korosec

35 M Korosec

36 M Korosec

37 M Korosec

38 M Korosec

39 M Korosec

40 M Korosec

41 M Reed

42 M Reed
Sample locality Rock

BA Ascension Island

$T$ Ascension Island

$R$ Ascension Island

R-F Ascension Island

- Ascension Island

$R$ Ascension Island

$R$ Ascension Island

T-F Ascension Island

BA Oregon Cascade

B Oregon Cascade

BA Oregon Cascade

B Oregon Cascade

B Oregon Cascade

B Oregon Cascade

B Oregon Cascade

$\mathrm{BA}$ Oregon Cascade

$B A$ oregon Cascade

B Oregon Cascade

BA Oregon Cascade

BA Oregon Cascade

B Oregon Cascade

B Oregon Cascade

B Oregon Cascade

B Oregon Cascade

D Los Azufres

A Los Azufres

$R$ Los Azufres

D Los Azufres

A Los Azufres

R Los Azufres

B Washington Cascade

BA Washington Cascade

B Washington Cascade

B Washington Cascade

B Washington Cascade

BA Washington Cascade

B Washington Cascade

A Washington Cascade

A Washington Cascade

B Washington Cascade

B Cerro Prieto

B Cerro Prieto
Sample Number

Researcher UAKA

AI-86-107

AI-86-102

AI $-86-103$

AI-86-103

AI-86-104

AI-86-105

AI-86-107

AI-88-16

CTGH-1-1756

ET-104

HC -180

BHS -20

BHS-21

BHS-22

PP-2

CTGH-1-3195

CTGH-1-4633

35-015

CTGH-1-3152

CTGH-1-4740

88-2-1819

88-4-810

88-3-1240

88-3-1741

\#1

\#2

\#3

\#4

$\# 5$

$\# 6$

MK-87-9-70

MK-87-9-75

MK-88-8-8

MK-88-8-9

MK-88-8-10

MK-88-8-11

MK-88-8-14

MK-88-8-18

MK-88-8-20

MK-88-8-24

CP-1

$\mathrm{CP}-2$
87040

87041

87042

87042

87043

87044

87045

88046

87016

87021

87022

87198

87199

87200

87218

88017

88018

88019

88040

88041

89063

89064

89065

89066

87238

87239

87240

87241

87242

87243

88163

88164

88165

88166

88167

88168

88169

88170

88171

88172

86252

86253
Reported Date

Ma $+/-$

0.66

0.03

0.92

0.02

1.15

0.03

0.99

0.04

0.06

0.02

0.82

0.65

2.92

2.35

4.96

0.86

1.47

0.65

0.94

5.15

4.64

0.63

4.95

4.65

0.15

0.07

1.35

1.49

1.09

5.92

0.90

0.45

1.36

0.13

0.13

0.31

0.22

0.31

0.49

0.28

1.67

0.20

0.29

0.39

0.10

0.12
0.01

0.02

0.02

0.08

0.14

0.37

0.06

0.06

0.05

0.05

0.25

0.12

0.09

0.23

0.12

0.05

0.03

0.07

0.06

0.03

0.14

0.03

0.03

0.06

0.01

0.01

0.05

0.12

0.08

0.08

0.02

0.23

0.04

0.03

0.04

0.06

0.07 
Sample type dated - groundmass feldspar concentrate or feldspar separate

Rock type

$$
\begin{aligned}
& \mathbf{A}=\text { Andesite } \\
& \mathbf{D}=\text { Dacite } \\
& \mathrm{O}=\text { Obsidian } \\
& \mathrm{T}=\text { Trachyte }
\end{aligned}
$$

$$
\begin{aligned}
& \mathrm{B}=\text { Basalt } \\
& \mathrm{BA}=\text { Basaltic andesite } \\
& \mathrm{R}=\text { Rhyolite } \\
& \mathrm{R}-\mathrm{F}=\text { Feldspar } \\
& \mathrm{T}-\mathrm{F}=\text { Feldspar }
\end{aligned}
$$

Affiliation of Researchers

$\mathrm{J}$ Moore

DL Nielson

G Priest

M Korosec

M Reed
UURI - Utah

UURI - Utah

Oregon Dept. of Geology and Mineral Industries Washington state Dept. of Natural Resources DOE- Geothermal Technology Division 